\title{
NATURAL RADIOACTIVITY OF GRANITES USED AS BUILDING MATERIALS IN GRECEE
}

Pavlidou, $S^{1}$., Koroneos, $A^{1}$., Papastefanou, $C^{2}$., Christofides, $G^{1}$., Stoulos, $S^{2}$. and Vavelides, $M^{1}$.

${ }^{1}$ Department of Mineralogy, Petrology, Economic Geology, School of Geology, Aristotle University of Thessaloniki. 54124 Thessaloniki, Macedonia, Greece.

${ }^{2}$ Laboratory of Atomic and Nuclear Physics, Aristotle University of Thessaloniki, Thessaloniki, 54124 Thessaloniki, Macedonia, Greece.

\section{ABSTRACT}

The granites used in Greece as building materials and imported from foreign countries, mainly from Spain and Brazil, are rock types similar with the stony building materials world-wide used. Sixteen kinds of different granites, considered as the most popular, were sampled and their natural radioactivity was measured by gamma spectrometry. The, ${ }^{226} \mathrm{Ra},{ }^{232} \mathrm{Th}$ and ${ }^{40} \mathrm{~K}$ contents of granites were compared to corresponding ones of other building materials as well as other granite types used all over the world. For the reasons of radiological impact from use of granites as building materials, the absorbed dose and the effective dose as well were determined. Although the annual effective dose is higher than the limit of $1 \mathrm{mSv}^{-1}$ for some granites examined, they could be used safely as building materials, considering that their contribution in most of the house constructions is very low. An attempt to correlate the relatively high level of natural radioactivity of different kinds of granites with the presence of radioactive minerals and their chemical composition was also made.

\section{INTRODUCTION}

It is very well known that the term 'granite' is world-wide used to describe not only granitic rocks considered and studied in igneous petrology, but also many other igneous rock-types used as building materials in the dimension stone market. The last few years, the use of granites as building material is very popular and the global amount of granite production is comparable to that of marble (Tsirambides 1996).

All types of building materials, including granites, have to be tested regarding their radioactivity. Radiation exposure of the population can be increased appreciably by the use of building materials containing above-normal levels of natural radionuclides, and is comparative or even greater than the exposure from the medical use of ionizing radiations (Stranden 1976). This paper is dealing with the natural radioactivity and the mineralogical and chemical study of granite building materials in order to understand and correlate the relationship of natural radioactivity with the radioactive mineral content and estimate possible implication from radiation exposure.

\section{MATERIALS AND METHODS}

The sixteen kinds of granite used in this study are the most popular types, according to the Hellenic Granites Corporation, that provided the samples. These were polished granite tiles ready for use and were collected at a granite factory unit.

Thin sections of the samples were studied under the polarized-light microscope in order to determine their mineralogical composition and investigate their texture. Polished thin sections were also prepared for the mineral chemistry. The LINK-AN 10000 Energy Dispersive System (EDS), attached on a JEOL JSM 840 Scanning Electron Microscope (SEM), were used to define the chemical composition of the minerals. Atomic absorption spectrometry was used to obtain the chemical 
A short description of each sample is given below, as it arises from a macroscopic and microscopic investigation, which are presented elsewhere (Pavlidou 2002). The colour of each sample is the colour of the polished tile, while the nomenclature is based on the Q'-ANOR chemical classification (Streckeisen \& Le Maitre 1979).

Salvatierra is a light gray, coarse-grained, porphyritic alkaligranite originating from Spain. It contains quartz, plagioclase, microcline, biotite, titanite, zircon, allanite and chlorite. The feldspars are kaolinized and sericitized.

Rosa porrino is a pinkish coarse-grained alkaligranite, with porphyritic structure, also from Spain. It contains quartz, plagioclase, microcline, biotite, zircon, allanite and a few chlorite. Its minerals are generally unaltered.

Blanco real is a white sample of medium- to coarse-grained alkaligranite originating from Spain. It is composed of quartz, plagioclase, microcline, biotite, muscovite, zircon, apatite and chlorite. The feldspars are kaolinized and sericitized.

Topazio is a yellow to light brown granite originating from Brazil. It contains quartz, plagioclase, orthoclase, biotite, garnet, actinolite, zircon and opaque minerals. This granite is slightly altered.

Yellow cecilia is a yellow-coloured coarse-grained granite with porphyritic structure. It comes from Brazil and its mineralogical composition is quartz, plagioclase, orthoclase, biotite, garnet, zircon and sillimanite. It is an almost unaltered sample.

Blanco crystal is a white, medium- to coarse-grained granite, coming from Spain. It contains quartz, plagioclase, orthoclase, biotite, titanite, zircon and chlorite. The feldspars are kaolinized and sericitized.

Napoleon is yellow-colored coarse-grained granite that originates from Brazil. It contains quartz, plagioclase, microcline, biotite, garnet, muschovite and zircon. The feldspars are kaolinized and sericitized.

Balmoral is a light-red coarse-grained granite. It is a finish granite containing quartz, plagioclase, microcline, biotite, muschovite, zircon, apatite, fluorite, monazite, epidote and chlorite. It is a rather unaltered sample.

African red is a dark-red coarse-grained granite from South Africa. It contains quartz, plagioclase, orthoclase, zircon and chlorite. The feldspars are totally kaolinized and sericitized and biotite is chloritized.

Multicolour is a medium- to coarse-grained granite with a gneiss-like structure of light red and dark gray zones. It comes from India and contains quartz, plagioclase, microcline, biotite, muscovite, zircon, apatite chlorite and opaque minerals. The feldspars are slightly kaolinized and sericitized.

Baltic brown is a dark brown, coarse-grained granite, with rapakivi texture (Haapala \& Rämö 1999), originating from Finland. It contains quartz, plagioclase, orthoclase, biotite, amphibole, zircon, apatite and opaque minerals. Orthoclase is kaolinized.

Gris perla is a white to light gray-coloured coarse-grained granite with, porphyritic structure. It is a spanish granite containing quartz, plagioclase, microcline, biotite, amphibole, titanite, zircon, apatite, allanite, epidote and chlorite. It is an almost unaltered sample.

Emerald is a black, iridescence, coarse-grained quartz monzonite, originating from Norway. It is called "larvikite". It contains alkali feldspar, biotite, amphibole, clinopyroxene, apatite and opaque minerals, and it is almost unaltered.

Marina pearl is a dark blue-gray iridescence, coarse-grained quartz monzonite coming from Norway. It is a "larvikite" like the Emerald sample. It contains alkali feldspar, biotite, clinopyroxene, olivine, zircon, apatite, allanite, epidote and opaque minerals, and is unaltered.

Zimbabwe is a black medium-grained quartz monzodiorite originating from South Africa. It contains quartz, plagioclase, orhtopyroxene, clinopyroxene and opaque minerals. It is unaltered.

Africa nero is a black to dark brown, medium-grained quartz gabbro originating from South Africa. It contains quartz, plagioclase, orhtopyroxene and clinopyroxene. It is almost unaltered.

The natural radioactivity $\left({ }^{238} \mathrm{U},{ }^{226} \mathrm{Ra},{ }^{232} \mathrm{Th}\right.$ and ${ }^{40} \mathrm{~K}$ content) of the samples was measured by gamma spectrometry (Manolopoulou 1990). All samples were crushed into grains less than $400 \mu \mathrm{m}$ in diameter, oven-dried at $60^{\circ} \mathrm{C}$ to constant weight, well-blended and measured using two highresolution gamma ray spectrometry systems. The first one consisted of a HPGe coaxial detector with $42 \%$ efficiency and $2.0 \mathrm{keV}$ resolution at $1.33 \mathrm{MeV}$ photons, shielded by 4 " $\mathrm{Pb}, 1 \mathrm{~mm} \mathrm{Cd}$ and 
$1 \mathrm{~mm} \mathrm{Cu}$ and the second one consisted of a LEGe planar detector with $0.7 \mathrm{keV}$ resolution at 122 keV photons, shielded by $1.3^{\prime \prime} \mathrm{Pb}, 1 \mathrm{~mm} \mathrm{Cd}$ and $1 \mathrm{~mm} \mathrm{Cu}$. The efficiency calibration of the gamma spectrometry systems was performed with the radionuclide specific efficiency method in order to avoid any uncertainty in gamma ray intensities as well as the influence of coincidence summation and self-absorption effects of the emitting gamma photons. A set of high quality certified reference materials (IAEA, RG-set) was used, with densities similar to the building materials measured after pulverization. Cylindrical geometry $(\varnothing 55 \mathrm{~mm}, \mathrm{~h}=20 \mathrm{~mm}$ ) was used assuming that the radioactivity is homogenously distributed in the measuring samples. The measurement duration was up to $200000 \mathrm{sec}$.

\section{RESULTS AND DISCUSSION}

The results of the specific activities and the average activity concentrations of ${ }^{238} U,{ }^{226} R_{a}{ }^{235} U$, ${ }^{232} \mathrm{Th}$ and ${ }^{40} \mathrm{~K}$ of sixteen granite samples examined are presented in tables 1 and 2 , respectively, while in figure 1 the activity concentrations of ${ }^{226} \mathrm{Ra},{ }^{232} \mathrm{Th}$ and ${ }^{40} \mathrm{~K}$ of the examined samples are compared. The average activity concentrations of the natural radionuclides of granites from different countries from all over the world reported by Chen \& Lin (1995), are shown in table 3, for comparison. The average activity concentrations of ${ }^{226} \mathrm{Ra},{ }^{232} \mathrm{Th}$ and ${ }^{40} \mathrm{~K}$ of the samples examined (Tab. 2) are slightly higher than those reported by Chen \& Lin (1995) for the granites of different countries all over the world.

Table 1. Activity concentrations of ${ }^{238} \mathrm{U},{ }^{226} \mathrm{Ra},{ }^{235} \mathrm{U},{ }^{232} \mathrm{Th}$ and ${ }^{40} \mathrm{~K}\left(\mathrm{~Bq} \mathrm{~kg}{ }^{-1}\right)$ of granites examined.

\begin{tabular}{llrrrrr}
\hline & Granite name & ${ }^{238} \mathrm{U}$ & ${ }^{226} \mathrm{Ra}$ & ${ }^{235} \mathrm{U}$ & ${ }^{232} \mathrm{Th}$ & ${ }^{40} \mathrm{~K}$ \\
\hline 1. & Salvatierra & $115 \pm 9$ & $118 \pm 2$ & $4.3 \pm 0.6$ & $77 \pm 2$ & $1320 \pm 33$ \\
2. & Rosa porrino & $61 \pm 5$ & $59 \pm 1$ & $2.5 \pm 0.8$ & $109 \pm 2$ & $1420 \pm 36$ \\
3. & Blanco Real & $96 \pm 5$ & $117 \pm 1$ & $5.3 \pm 1.0$ & $95 \pm 1$ & $1233 \pm 30$ \\
4. & Topazio & $32 \pm 5$ & $29 \pm 1$ & $1.5 \pm 0.6$ & $44 \pm 1$ & $1327 \pm 33$ \\
5. & Yellow cecilia & $<\mathrm{MDA}$ & $19 \pm 1$ & $1.0 \pm 0.5$ & $30 \pm 1$ & $1020 \pm 26$ \\
6. & Blanco crystal & $163 \pm 9$ & $163 \pm 2$ & $7.0 \pm 0.7$ & $91 \pm 2$ & $1190 \pm 30$ \\
7. & Napoleon & $<\mathrm{MDA}$ & $11 \pm 2$ & $<\mathrm{MDA}$ & $46 \pm 1$ & $1200 \pm 30$ \\
8. & Balmoral & $174 \pm 7$ & $170 \pm 1$ & $7.7 \pm 1.3$ & $354 \pm 3$ & $1592 \pm 39$ \\
9. & African red & $98 \pm 5$ & $80 \pm 1$ & $4.2 \pm 1.2$ & $121 \pm 1$ & $1421 \pm 32$ \\
10. & Multicolour & $<\mathrm{MDA}$ & $11 \pm 1$ & $1.0 \pm 0.5$ & $84 \pm 2$ & $926 \pm 23$ \\
11. & Baltic brown & $64 \pm 6$ & $60 \pm 1$ & $2.9 \pm 0.7$ & $57 \pm 1$ & $1350 \pm 34$ \\
12. & Gris perla & $67 \pm 5$ & $70 \pm 1$ & $3.2 \pm 0.5$ & $43 \pm 1$ & $1340 \pm 34$ \\
13. & Emerald & $50 \pm 4$ & $55 \pm 1$ & $2.5 \pm 1.2$ & $63 \pm 1$ & $1053 \pm 24$ \\
14. & Marina pearl & $29 \pm 3$ & $35 \pm 1$ & $1.1 \pm 0.5$ & $37 \pm 1$ & $894 \pm 22$ \\
15. & Zimbabwe & $19 \pm 4$ & $20 \pm 1$ & $<\mathrm{MDA}$ & $32 \pm 1$ & $332 \pm 14$ \\
16. & Africa nero & $<\mathrm{MDA}$ & $1.6 \pm 0.3$ & $<\mathrm{MDA}$ & $<\mathrm{MDA}$ & $49 \pm 4$ \\
\hline
\end{tabular}

$\mathrm{MDA}=$ minimum detectable activity; ${ }^{238} \mathrm{U}: 9 \mathrm{~Bq} \cdot \mathrm{kg}^{-1} ;{ }^{235} \mathrm{U}: 1 \mathrm{~Bq} \cdot \mathrm{kg}^{-1} ;{ }^{232} \mathrm{Th}: 1 \mathrm{~Bq} \cdot \mathrm{kg}^{-1}$

Table 2. Average activity concentration of the natural radionuclides $\left(\mathrm{Bq} \mathrm{kg}^{-1}\right)$ of granite samples examined.

\begin{tabular}{lrrrr}
\hline Nuclide & ${ }^{238} \mathrm{U}$ & ${ }^{226} \mathrm{Ra}$ & ${ }^{232} \mathrm{Th}$ & ${ }^{40} \mathrm{~K}$ \\
\hline Average & 61 & 64 & 81 & 1104 \\
Standard deviation & 56 & 53 & 79 & 407 \\
Range & $<$ MDA -174 & $2-170$ & $<$ MDA - 354 & $49-1592$ \\
MDA & 9 & 1 & 2 & 12 \\
\hline
\end{tabular}

MDA = minimum detectable activity 
Table 3. Average activity concentrations of the natural radionuclides $\left(\mathrm{Bq} \mathrm{kg}^{-1}\right)$ of 137 granite samples from different countries all over the world*.

\begin{tabular}{lrrr}
\hline Nuclide & ${ }^{226} \mathrm{Ra}$ & ${ }^{232} \mathrm{Th}$ & ${ }^{40} \mathrm{~K}$ \\
\hline Average & 42 & 73 & 1055 \\
Standard deviation & 35 & 51 & 357 \\
Range & $0.2-160$ & $<\mathrm{MDA}-253$ & $<\mathrm{MDA}-2355$ \\
MDA & 0.2 & 4.0 & 36.0 \\
\hline
\end{tabular}

MDA = minimum detectable activity

${ }^{*}$ Chen and Lin (1995)

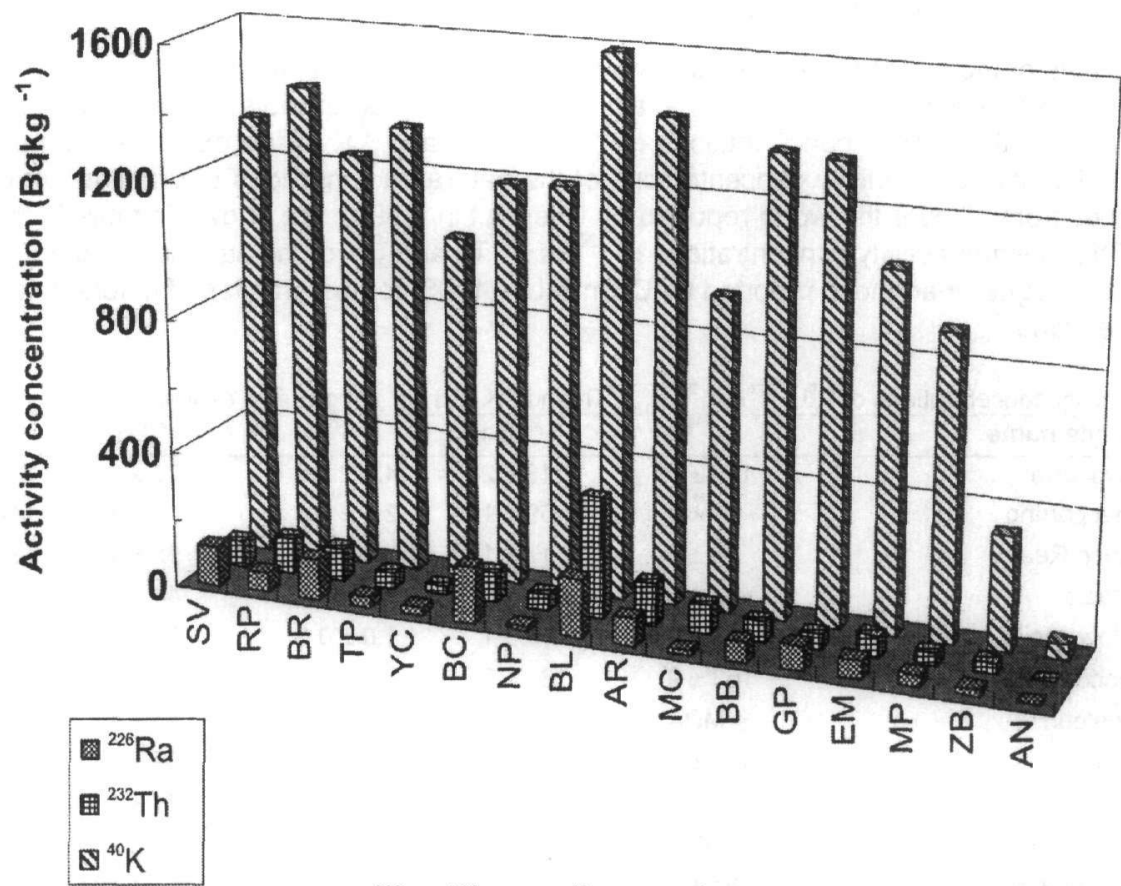

Figure 1. The activity concentrations of ${ }^{226} \mathrm{Ra},{ }^{232} \mathrm{Th}$ and $\left.{ }^{40} \mathrm{~K}(\mathrm{~Bq} \mathrm{~kg})^{-1}\right)$ of the granite samples examined. SV: Salvatierra, RP: Rosa porrino, BR: Blanco real, TP: Topazio, YC: Yellow Cecilia, BC: Blanco crystal, NP: Napoleon, BL: Balmoral, AR: African red, MC: Multicolour, BB: Baltic brown, GP: Gris perla, EM: Emerald, MP: Marina pearl, ZB: Zimbabwe and AN: Africa nero.

The mean activity concentrations of ${ }^{226} \mathrm{Ra},{ }^{232} \mathrm{Th}$ and ${ }^{40} \mathrm{~K}$ of the granite samples examined were compared to those of different building materials (Zikovsky \& Kennedy 1992) and the earth's crust (UNSCEAR 2000) (Tab. 4). It is pointed out that the natural radionuclide content of granites of the present study is relatively high, just like those of all granite types referred in the literature (Chen \& Lin 1995), compared to other building materials, such as concrete, brick and clay brick, gypsum, gravel, glass wool, tile, glass and wood (Fig. 2). The latter has the lowest natural radionuclide content, while some kinds of concrete; brick and tile show relatively high natural radioactivity in contrast to gypsum and glass.

In order to assess the radiological impact of granites used as building materials, the model of a cubic building $3 \mathrm{~m} \times 3 \mathrm{~m} \times 3 \mathrm{~m}$, infinite thin walls and no doors and windows (standard room model) was considered (UNSCEAR 1993).

The absorbed dose rate was determined by the following formula:

$D\left(n \mathrm{~Gy} \mathrm{~h}^{-1}\right)=\alpha_{1} \mathrm{C}_{40 \mathrm{~K}}+\alpha_{2} \mathrm{C}_{232 \mathrm{Th}}+\alpha_{3} \mathrm{C}_{226 \mathrm{Ra}}$

where:

$\mathrm{C}_{40 \mathrm{~K}}, \mathrm{C}_{232 \mathrm{Th}}, \mathrm{C}_{226 \mathrm{Ra}}=$ the specific activity of ${ }^{40} \mathrm{~K},{ }^{232} \mathrm{Th}$ and ${ }^{226} \mathrm{Ra}$ respectively, in $\mathrm{Bq} \mathrm{kg}{ }^{-1}$ 
$\alpha_{1}=0,0414 n \mathrm{~Gy} \mathrm{~h}^{-1} / \mathrm{Bq} \mathrm{kg}^{-1}$
$\alpha_{2}=0,623 n \mathrm{~Gy} \mathrm{~h}^{-1} / \mathrm{Bq} \mathrm{kg}^{-1}$
$\alpha_{3}=0,461 n \mathrm{~Gy} \mathrm{~h}^{-1} / \mathrm{Bq} \mathrm{kg}^{-1}$

The annual effective dose limit was considered 1 to $2 \mathrm{mSv}$.

Table 5 shows the absorbed dose rate $D\left(n \mathrm{Gyh}^{-1}\right)$ and the annual effective dose $D_{a}(m S v)$ estimated for the granite samples examined. Corresponding data for the mean soil composition (UNSCEAR 1993) are included for comparison. It is concluded that the absorbed dose for people living in dwellings made of the granites examined would be higher than the absorbed dose for those living in dwellings made of building materials having the mean soil composition except for the case of granites Zimbabwe and Africa nero. Moreover, the annual effective dose $D_{a}$ (UNSCEAR 1993) exceeds the limit of $1 \mathrm{mSv}$ for six samples (Tab. 5) as follows: Salvatierra (1.4 mSv), Rosa porrino (1.4 mSv), Blanco real (1.4 mSv), Blanco crystal $(1.6 \mathrm{mSv})$, Balmoral (3.2 mSv), African red (1.5 $\mathrm{mSv}$ ). However, granite, being a relatively expensive material, is only used on floors, tables, exterior walls, fire places and other decorations, and as a result, its contribution in most of the building constructions is relatively low. So, granite would contribute to the level of natural radioactivity, but it wouldn't be responsible for exceeding the $1 \mathrm{mSv}$ dose limit.

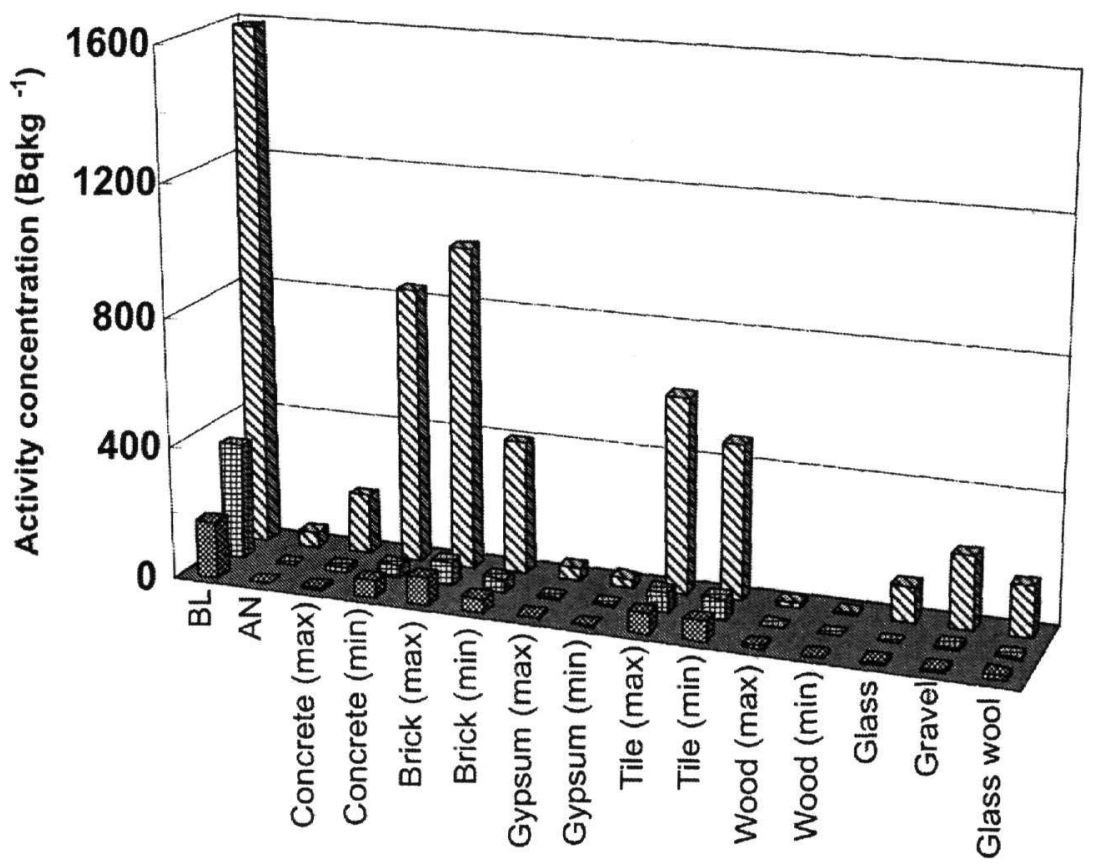

Figure 2. The activity concentrations of ${ }^{226} \mathrm{Ra},{ }^{232} \mathrm{Th}$ and ${ }^{40} \mathrm{~K}\left(\mathrm{~Bq} \mathrm{~kg}^{-1}\right)$ of the granite samples $\mathrm{BL}$ (Balmoral) and AN (Africa nero), having the maximum and the mininum annual effective dose $D_{a}$ among the examined samples, are compared to maximum $(\max )$ and minimum $(\mathrm{min}$ ) activity concentrations of different building materials (Zikovsky \& Kennedy 1992). Symbols as in figure 1.

There has been an attempt to correlate the mineral composition of granites to the relatively high level of natural radioactivity. According to Heinrich (1958), natural radioactivity of igneous rocks is mostly attributed to the chemical composition of minerals that they contain and to a lesser extend to fluid inclusions in minerals and intergranular fluids. Some minerals contain radioactive nuclides either as basic elements in their chemical composition or as elements that substitute the basic ones. Table 5 shows the accessory minerals found in all samples that could be radioactive, according to Heinrich (1958), if they contain Uranium or Thorium compounds. 
Table 4. Average activity concentrations of ${ }^{226} \mathrm{Ra},{ }^{232} \mathrm{Th} \mathrm{kal}{ }^{40} \mathrm{~K}\left(\mathrm{~Bq} \mathrm{~kg}{ }^{-1}\right)$ of building materials from different countries all over the world ${ }^{1}$ granites ${ }^{2.3}$ and Earths crust ${ }^{4}$.

\begin{tabular}{lrrrr}
\hline Material & Number of samples & ${ }^{226} \mathrm{Ra}$ & ${ }^{232} \mathrm{Th}$ & ${ }^{40} \mathrm{~K}$ \\
\hline Concrete (UK) & 21 & 19 & 11 & 183 \\
Concrete (Spain) & 24 & 30 & 32 & 204 \\
Concrete (Canada) & 13 & 11 & 17 & 488 \\
Concrete (Finland) & 15 & 53 & 38 & 838 \\
\hline Brick (Germany) & 109 & 59 & 67 & 670 \\
Brick (Canada) & 6 & 44 & 59 & 404 \\
Brick-clay (UK) & 25 & 52 & 44 & 640 \\
Brick-clay (Spain) & 11 & 68 & 56 & 416 \\
Brick-clay (Netherlands) & 14 & 39 & 41 & 560 \\
Brick-clay (Finland) & 38 & 80 & 62 & 986 \\
\hline Gypsum-chemical (Canada) & 3 & 33 & 31 & 79 \\
Gypsum-natural (Canada) & 3 & 4 & 5 & 40 \\
Gypsum-natural (Finland) & 1 & 7 & 1 & 25 \\
\hline Gravel (Canada) & 3 & 10 & 12 & 222 \\
\hline Glass wool (Finland) & 8 & 16 & 7 & 157 \\
\hline Tile (Canada) & 15 & 61 & 66 & 476 \\
Tile (Netherlands) & 8 & 61 & 66 & 600 \\
\hline Glass (Netherlands) & 2 & 8 & 2 & 110 \\
\hline Wood (Netherlands) & 2 & 10 & 4 & 19 \\
Wood (Finland) & 2 & 0 & 1 & 10 \\
\hline Granites ${ }^{2}$ & 16 & 61 & 82 & 1061 \\
Granites ${ }^{3}$ & 167 & 42 & 73 & 1055 \\
Earth's crust ${ }^{4}$ & - & 35 & 30 & 400 \\
\hline Zikovsy \& Kenn & & & 5 \\
\hline
\end{tabular}

'Zikovsky \& Kennedy (1992), ${ }^{2}$ Present study, ${ }^{3}$ Chen \& Lin (1995), ${ }^{4}$ UNSCEAR (2000).

Table 5. Potentially radioactive accessory minerals in the granite samples examined, absorbed dose rate $D$ $\left(n G y ~^{-1}\right)$, annual effective dose $D_{a}(m S v)$ for the samples and the mean soil composition.

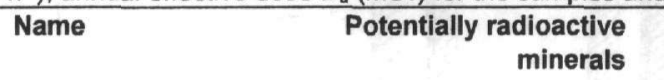

1. Salvatierra

2. Rosa porrino

3. Blanco real

4. Topazio

5. Yellow cecilia

6. Blanco crystal

7. Napoleon

8. Balmoral

9. African red

10. Multicolour

11. Baltic brown

12. Gris perla

13. Emerald

14. Marina pearl

15. Zimbabwe

16. Africa nero

Mean soil composition*
Absorbed dose rate

D (UNSCEAR 1993)

(nGy hi)

157.2

153.9

164.2

95.7

69.7

181.1

83.4

364.8

171.1

95.7

119.1

114.5

108.2

76.2

42.9

2.8

43.5
Annual effective dose

$D_{a}$ (UNSCEAR 1993) (mSv)

1.4

1.4

1.4

0.8

0.6

1.6

0.7

3.2

1.5

0.8

1.0

1.0

1.0

0.7

0.4

0.0

0.4

*UNSCEAR (1993), Tit=titanite, $\mathrm{Zr}=$ zircon, Ap=apatite, Fl=fluorite, All=allanite, Mz=monazite, Py=pyrite, Hem=hematite, IIm=ilmenite. 
Due to its high specific activity of ${ }^{232} \mathrm{Th}\left(354 \pm 3 \mathrm{~Bq} \mathrm{~kg}^{-1}\right)$, Balmoral granite appears to have the higher annual effective dose $\left(\mathrm{D}_{\mathrm{a}}=3.2 \mathrm{mSv}\right)$. Furthermore, monazite with high amount of $\mathrm{ThO}_{2}$ $(4.00 \%)$ has been found in its mineralogical composition. The chemical composition of monazite in this sample is shown in table 6 . Consequently, the high level of natural radioactivity of Balmoral granite is attributed to its monazite content. Also, this sample contains other minerals, such as zircon, apatite and fluorite, which could contain radioactive nuclides in their chemical composition and thus contribute to the level of natural radioactivity of the sample.

Monazite has also been found in the samples Blanco real $\left(D_{a}=1.4 \mathrm{mSv}\right)$ and Blanco crystal $\left(D_{a}=\right.$ $1.6 \mathrm{mSv}$ ). Its presence in these samples could justify the natural radioactivity caused by Thorium (Tab. 6).

Table 6. Average electron microprobe analysis of monazite of the samples Blanco real (BR), Blanco crystal (BC) and Balmoral (BL).

\begin{tabular}{lrrr}
\hline Sample & BR & BC & BL \\
Number of analyses & 4 & 3 & 6 \\
\hline Oxides \% w/W & & & \\
$\mathrm{SiO}_{2}$ & 0.00 & 0.00 & 2.88 \\
$\mathrm{P}_{2} \mathrm{O}_{5}$ & 30.27 & 34.19 & 30.02 \\
$\mathrm{Y}_{2} \mathrm{O}_{3}$ & 13.55 & 33.60 & 3.71 \\
$\mathrm{La}_{2} \mathrm{O}_{3}$ & 10.65 & 3.48 & 16.04 \\
$\mathrm{Ce}_{2} \mathrm{O}_{3}$ & 21.11 & 7.85 & 28.89 \\
$\mathrm{Pr}_{2} \mathrm{O}_{3}$ & 1.70 & 1.12 & 2.76 \\
$\mathrm{Nd}_{2} \mathrm{O}_{3}$ & 7.89 & 4.33 & 8.27 \\
$\mathrm{Sm}_{2} \mathrm{O}_{3}$ & 0.75 & 0.83 & 0.82 \\
$\mathrm{Gd}_{2} \mathrm{O}_{3}$ & 0.62 & 2.76 & 1.26 \\
$\mathrm{Dy}_{2} \mathrm{O}_{3}$ & 1.12 & 4.11 & 0.49 \\
$\mathrm{ThO}_{2}$ & 8.34 & 5.01 & 4.00 \\
$\mathrm{UO}_{2}$ & 1.67 & 0.82 & 0.00 \\
$\mathrm{Total}$ & 97.66 & 98.09 & 99.13 \\
\hline
\end{tabular}

All the other samples of granites resulting in an annual effective dose higher than $1 \mathrm{mSv}$ (Tab. 5), contain accessory minerals that, according to Heinrich (1958), could contain radioactive nuclides in the form of $U$ - or Th-compounts. It is obvious that the rest of the samples, contain possibly radioactive minerals as well. It must be their quantity and their particular chemical composition that have a specific effect on the level of natural radioactivity of each sample.

Another interesting point is that the two red granite samples, i.e. Balmoral and African red, show relatively enhanced radioactivity. It is remarkable that most of the granite samples with high radioactivity examined by Chen \& Lin (1995) were also red. As for the other highly radioactive samples, one of them was light gray (Salvatierra), two were white (Blanco real and Blanco crystal) and one was pink (Rosa porrino).

The red colour of Balmoral and African red granites is due to the more abundant minerals, the feldspars that are reddish in colour. The red colour of feldspars is due to hematite inclusions (Smith \& Brown 1988). Electron microprobe analysis of feldspars in Balmoral and African red granites show relatively high amounts of $\mathrm{Fe}$, as it is shown in table 7 , which could justify the presence of such inclusions. According to Heinrich (1958), hematite could be radioactive, containing small amounts of Uranium. Thus, it is possible that hematite inclusions in feldspars might contribute to the level of natural radioactivity of Balmoral and African red granites. 
Table 7. Average electron microprobe analysis of feldspars of the samples African red $(A R)$ and Balmoral $(B L)$.

\begin{tabular}{|c|c|c|c|}
\hline Sample & BL & AR & $\overline{A R}$ \\
\hline Feldspar type & Mi & Or & $\mathbf{P I}$ \\
\hline Number of analyses & 3 & 2 & 2 \\
\hline \multicolumn{4}{|l|}{ Oxides \%w/w } \\
\hline $\mathrm{SiO}_{2}$ & 65.37 & 64.85 & 65.13 \\
\hline $\mathrm{TiO}_{2}$ & 0.04 & 0.35 & 0.00 \\
\hline $\mathrm{Al}_{2} \mathrm{O}_{3}$ & 18.46 & 18.02 & 20.67 \\
\hline $\mathrm{FeO}$ & 0.18 & 0.87 & 1.29 \\
\hline $\mathrm{CaO}$ & 0.00 & 0.00 & 0.85 \\
\hline $\mathrm{Na}_{2} \mathrm{O}$ & 1.50 & 2.44 & 10.66 \\
\hline $\mathrm{K}_{2} \mathrm{O}$ & 14.16 & 12.54 & 0.58 \\
\hline $\mathrm{BaO}$ & 0.14 & 0.44 & 0.33 \\
\hline Total & 99.84 & 99.51 & 99.50 \\
\hline
\end{tabular}

$\mathrm{Mi}=$ Microcline, Or $=$ Orthoclase, $\mathrm{PI}=$ Plagioclase

\section{REFERENCES}

Chen C.J. \& Lin Y.M. 1995. Assessment of building materials for compliance with regulations of ROC. Environment international, 22, 221-226.

Haapala I. \& Rämö O.T. 1999. Rapakivi granites and related rocks: an introduction. Precambrian Research, 95, 1-7.

Heinrich W. M. E. 1958. Mineralogy and geology of radioactive raw materials. McGraw-Hill Book Company, New York, $643 \mathrm{pp}$.

Manolopoulou M. 1990. A radioecological study of the coal power plant environment. PhD Thesis, Aristotle University of Thessaloniki, Thessaloniki, Greece, $178 \mathrm{pp}$ (in Greek with English abstract).

Pavlidou S. 2002. Imported plutonic rocks used in Greece us building materials: mineralogy, petrology, geochemistry, natural radioactivity and technical properties. Master Thesis, Aristotle University of Thessaloniki, Thessaloniki, Greece, $100 \mathrm{pp}$ (in Greek).

Smith V.J. \& Brown L.W. 1988. Feldspar minerals. 1. Crystal structures, physical, chemical and microtextural properties. Springer-Verlag, Berlin, Heiderberg, New York, London, Paris, Tokyo, 828 pp.

Stranden E. 1976. Some aspects on radioactivity of building materials. Physica Norv., 8, 167-173.

Streckeisen A. \& Le Maitre R. W. 1979. A chemical approximation to the modal QAPF classification of igneous rocks. Neues Jahrb. Mineral. Abh., 136, 169-206.

Tsirambides A. 1996. The Greek marbles and other decorative stones. University Studio Press, Thessaloniki, $310 \mathrm{pp}$ (in Greek).

United Nations Scientific Committee on the Effects of Atomic Radiation (UNSCEAR) 1993. Sources and Effects of lonizing Radiation. United Nations Sales Publication, New York.

United Nations Scientific Committee on the Effects of Atomic Radiation (UNSCEAR) 2000. Sources and Effects of lonizing Radiation. Vol. I, United Nations Sales Publication, New York, 654 pp.

Zikovsky L. \& Kennedy G. 1992. Radioactivity of building materials available in Canada. Health Physics, 63(4), 449-452. 